\title{
Hegel and Rancière on the Transformation of Self-Conceptions and the Achievement of Freedom and Self-Sufficiency
}

Stephen W. Enciso, Department of Philosophy, Monash University

\begin{abstract}
Freedom and self-sufficiency are central human concerns, but what do these terms mean and how are they related to social justice? In this article, I look at two distinct understandings of these terms. For both Hegel and Rancière, freedom and self-sufficiency consist in the transformation of self-conceptions, but for Hegel the identification with the product of one's labour is essential, whereas for Rancière it is not. Further, freedom and self-sufficiency for Hegel are permanent achievements, whereas for Rancière they are processes that must continually be put into practice. The implications of this difference have to do with social recognition: are individuals and identity-groups 'finally' free when they are assimilated into the social order, or must they always fight to be recognised? Rancière takes the latter perspective and I end by noting the political importance of his cynicism towards moments of social recognition and reconciliation.
\end{abstract}

Keywords: Freedom and self-sufficiency, mastery and servitude, transformation of self-conceptions, dialectical process, social reconciliation, distribution of the sensible

\section{Introduction}

Freedom and self-sufficiency are central human concerns, but what do these terms mean and how are they related to social justice? Isaiah Berlin (2002) famously made the distinction between negative freedom, i.e. freedom from, and positive freedom, i.e. freedom to. Hegel and Rancière both give an account of freedom that falls approximately into the latter category, freedom to, in the sense that freedom, for them, is about putting into practice one's capacities and actualising a more accurate kind of being. Self-sufficiency is related to freedom in that it has to do with one's capacity to be an autonomous agent interacting with the world on one's own terms.

For both thinkers, the achievement of freedom and self-sufficiency depends on changes in the way we conceive of ourselves. However, they also recognise that our self-conceptions are actually quite bound up with the way that others conceive of us. That is to say, our self-conceptions are not independent from our embeddedness within a social order and its practices of recognition. Given that those who are not recognised, or who are mis-recognised, by the social order, suffer forms of oppression and find themselves marginalised, recognition is an essential condition of social justice.

In this article, I undertake a comparison between Hegel and Rancière on what the transformation of self-conceptions consists in, the nature of the resulting achievement of freedom and self-sufficiency, and the relationship of these terms to social justice.

I begin with Hegel. While Hegel gives a comprehensive account of freedom and its relationship to social institutions and the ethical life in Philosophy of Right (originally published in 1820), I here restrict my analysis to the passages in Phenomenology of Spirit (originally published in 1807) dealing with the life and death struggle and the master-servant relationship. It is useful to focus on these passages alone for the purposes of comparison because the figure of the servant, the character representing the marginalised position in social relations, illuminates important aspects of the relationship between self-conceptions and recognition, in the first instance, and freedom and self-sufficiency in the second. In particular, through the figure of the servant we see that, for Hegel, identification with the product of one's labour is a crucial part of the transformation of self-conception, and that the dialectical process through which this transformation takes place makes freedom and self-sufficiency permanent achievements.

I then turn to Rancière. Rancière has written extensively on the politics of aesthetics and the aesthetics of politics, over the years developing some important vocabulary for political theory. For the purposes of this comparison, I focus on one of his key concepts, the distribution of the sensible, given its affinity with Hegel in the importance placed on the transformation of self-conceptions. The transformation of self-conceptions, for Rancière, also has to do with labour, but the crucial difference with Hegel is that, for Rancière, this transformation does not arise from an identification with the product of one's labour, but rather with the desire to be free of labour altogether. Furthermore, Rancière does not subscribe to Hegel's dialectical process and so, for him, transformations of self-conceptions are inherently unstable. Freedom and self-sufficiency are not permanent achievements but more like processes that must continually be put into practice. 
Conceptualising these terms as inherently unstable is Rancière's contribution to thinking social justice. Rancière encourages cynicism about moments of social recognition or reconciliation, in order to avoid the trap of thinking that politics has come to an end and that there is no more injustice to be resisted. I end by noting the importance of a contemporary project to politicise certain critical theories using a Rancièrean framework, in order to ensure they are adequately resourced to do the work we need them to do in diagnosing social ills and facilitating political action.

\section{The Hegelian story}

This story for us begins in the section of Phenomenology entitled 'Self-Consciousness', which follows 'Consciousness'. In 'Consciousness', Hegel has focused on understanding how objects appear to us and how we acquire knowledge about them. Through his signature dialectical process, he has brought the reader to the position that the Kantian noumenal world of things-in-themselves inaccessible to consciousness is mistaken: we can and do have knowledge about objects in the world as they actually are. Furthermore, consciousness is revealed to be not something separate from the sensible world and the objects in it, but something which is crucially involved in the constitution of the world and its objects. Thus, Subject (i.e. consciousness) and Object mutually inform, and depend on, each other - this is the truth that Hegel believes has been established by the end of this chapter. In the next chapter, 'Self-Consciousness', the focus turns to the self and social relations.

How do we acquire knowledge about ourselves as individuals and as social groups? Hegel's answer is that selfconsciousness depends on mutual recognition. He writes:

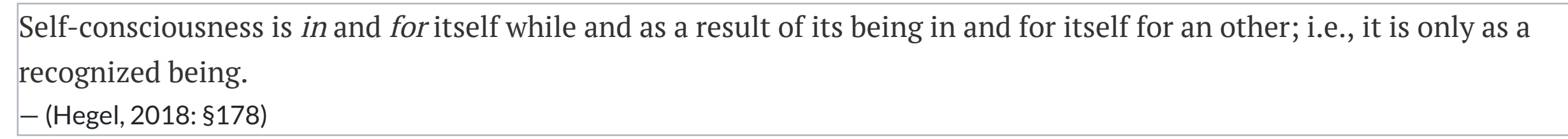

Each [self-consciousness] is, to itself, and in that of the other, an essence immediately existing for itself which at the same time is for itself in that way only through this mediation. They recognize themselves as mutually recognizing each other.

- (Hegel, 2018: §184)

The idea is that, for my sense of self, I depend on the recognition by another of my essential qualities. The relation of recognition is prior to individuality and, in fact, constitutes individuality. The priority of the relationship of recognition entails the priority of the social over the individual: each individual is a product of mutual recognition, an ' $I$ that is a we and [a] we that is an $I$ (Hegel, 2018: §177). The way Hegel arrives at this position is rather involved.

A key part of the story is the life and death struggle. The life and death struggle is an allegory about two individuals/selfconsciousnesses and the way in which their self-conceptions come to be undermined through a dialectical process. As Houlgate (2013: 93) explains, the tale begins with the two individuals believing themselves to be completely free and selfsufficient and believing the other to be unfree and non-self-sufficient. Each individual initially takes the other not to be a self-consciousness, a whole person, but to be a mere thing or object: "They are for each other in the way that ordinary objects [are]' (Hegel, 2018: §186). By contrast to the way it conceives of the other, each individual takes its own freedom to consist in not being determined by mere things and, crucially, in not being attached to life. As Brandom explains, the reason that freedom, for Hegel, consists in not being attached to life, is that an essential element of being self-conscious is the capacity for self-constitution by identification (Brandom, 2011:28-30). I can risk my life for the sake of a moral or political principle, thereby demonstrating, by identifying with this principle, that I am not limited to my biological existence. My self-conception thus plays an important role in determining who I am, over and above what I am.

Continuing on with the story: the two individuals find themselves in a violent struggle, risking their lives in order to kill the other, thus demonstrating how little life matters to them. But, very quickly, the individuals realise that what they most desire is to be recognised as having the sort of freedom that consists in being unattached to life. If they succeed in killing the other, then the other cannot recognise them as free. Thus, says Hegel, 'in this experience self-consciousness learns that life is as essential to it as is pure self-consciousness' (Hegel, 2018: §189). The struggle to the death loses all meaning when the individual realises that the other must be kept alive in order to perform the act of recognition that is crucial to the sense of freedom and self-sufficiency. 
The situation that subsequently arises is not, however, one of equality between the two individuals. What ends the life and death struggle is the imposition of an asymmetrical order of recognition. One of the individuals continues to regard itself as free and self-sufficient and unattached to life, but it knows it can no longer prove this freedom by killing the other, so it is content to subordinate the other instead. Hegel describes the situation that arises between the two individuals:

One is self-sufficient; for it, its essence is being-for-itself. The other is non-self-sufficient; for it, life, or being for an other, is the essence. The former is the master, the latter is the servant.

- (Hegel, 2018: §189)

One individual's freedom comes to consist in holding another individual in a subordinate position and demanding of that individual that it recognise the first as superior.

At this stage in the story, the master's conception of himself (Hegel here uses a masculine construction) as free and selfsufficient, as a 'pure being-for-itself' (Hegel, 2018: §186), relies on his privileged position in relation to the servant. The master, as Hegel puts it, does not have to confront the self-sufficiency, or independence, of other objects in the world, because the master 'only links up with the non-self-sufficiency of the thing and simply consumes it. He leaves the aspect of its self-sufficiency in the care of the servant, who works on the thing' (Hegel, 2018: §190). The master has this idea of himself as absolutely powerful, but the self-conception of his freedom and self-sufficiency relies on the interposition of the servant between himself and the objects of the world that must be transformed in order to be enjoyed. It is the servant who confronts the self-sufficiency of objects through the activity of labour. For example, the servant harvests raw ingredients and combines them, transforms them, in the cooking process, for the master's consumption. The master is deluded about his sense of freedom and self-sufficiency because he does not acknowledge just how dependent he is on the servant's labour.

This allegory about the life and death struggle and the resulting master-servant relation bears striking similarities to analyses about the asymmetrical structure of the social order with its dominant or ruling class and its subordinate class. Houlgate (2013: 96), for example, has acknowledged the evocation here of Marx's analysis of the relations of production between capitalists and proletarians. But, whereas Marx sets out objective, historical processes of production, Hegel is more interested in how the self-conceptions of the master and the servant come to be transformed through a dialectical process (Houlgate, 2013: 96-97).

At this stage in the story, the feeling of absolute power and freedom belongs to the self-conception of the master, while the necessity of labour and the feeling of subordination belongs to the self-conception of the servant. Through a dialectical process, the master comes to recognise that he is less free and less self-sufficient than he initially thought, and the servant comes to realise that he is more free and more self-sufficient than he initially thought. Hegel writes:

The inessential consciousness is therein for the master the object which constitutes the truth of his certainty of himself. However, it is clear that this object does not correspond to its concept, but rather that the object in which the master has achieved his mastery has become, to the master, something entirely different from a self-sufficient consciousness. It is not a self-sufficient consciousness which is for him but above all a non-self-sufficient consciousness. His certainty is therefore not that of being-for-itself as the truth; instead, his truth is the inessential consciousness and the inessential doing of that inessential consciousness.

- (Hegel, 2018: §192)

The truth of the self-sufficient consciousness is thus the servile consciousness. To be sure, this consciousness admittedly first appears external to itself and not as the truth of self-consciousness. However, in the way that mastery showed that its essence is the inversion of what mastery wants to be, so too in its consummation will servitude become instead the opposite of what it immediately is. As a consciousness forced back into itself, it will take the inward turn and convert itself into true self-sufficiency.

- (Hegel, 2018: §193)

The master becomes aware of his dependence on the servant (the 'servile consciousness'), he becomes aware that, without the servant, his sense of absolute power over things and his feeling of freedom and self-sufficiency mean nothing. Thus, the master recognises that his 'essence is the inversion of what mastery wants to be'. He is not and could never be what he had thought himself to be. 
As for the servant's transformation of self-conception, the one we are more interested in from the perspective of social justice, it is not as straightforward as the master's. The phrase, 'so too in its consummation will servitude become instead the opposite of what it immediately is', could suggest that the servant eventually becomes the master of the master, as Hyppolite (1974: 172) has argued. But Houlgate (2013: 98) argues for an alternative interpretation, one in which the servant does acquire a greater sense of his freedom and self-sufficiency, but only 'within the limits of servitude'. That is to say, the servant's freedom does not consist in the abolition of servitude, but in a changed relationship to servitude.

Let us see how the servant's self-conception changes. Whereas the master initially conceives of himself as absolutely free and self-sufficient, the servant conceives himself as not free and not self-sufficient because he is bound to and defined by his labour and his life. Even so, Hegel says, the servant does have the opportunity to participate in the master's sense of absolute power through the experience of the fear of death. In the fear of death, the servant experiences the same feeling as the master of being nothing (i.e. being attached, not to life or things, but only to one's self-conception) (Hegel, 2018: $\S 194)$. By realising his similarity to the master in this respect, the servant makes some progress towards being 'pure beingfor-itself, or free and self-sufficient. But this is only half of the servant's story.

What completes the servant's realisation of his 'true self-sufficiency' (Hegel, 2018: §193) is the realisation that his labour is the expression of himself. Hegel says that in the experience of the servant, labour has a two-fold character. On the one hand, labour is something the servant is forced to do by the master, but on the other hand, labour is also that which is properly the servant's own activity, that which is an expression of his own capacities. The servant sees, in the selfsufficient product of his labour, the embodiment of his own identity. Hegel writes: 'The working consciousness comes to an intuition of self-sufficient being as its own self (Hegel, 2018: §195); 'being-for-itself [i.e. the product] becomes for him [the servant] his own being-for-itself, and he attains the consciousness that he himself is in and for himself' (Hegel, 2018: $\S 196)$. Houlgate (2013: 101) explains that what is crucial to this picture is that the servant sees embodied in the product of his labour, not only his freedom to create particular things, but also the conception of himself as nothing in the face of death.

The servant thus comes to the realisation that he is essentially free and self-sufficient, in ways similar to the master, albeit within the limits of his servitude. As Hegel writes: 'He comes to acquire through himself a mind of his own, and he does this precisely in the work in which there had seemed to be only some outsider's mind' (Hegel, 2018: §196). The servant's freedom and self-sufficiency consist in the transformation of his self-conception, which transformation is based on the identification with the product of his labour.

Even if it is true, as Williams (1997: 172) has suggested, that the dialectic of the master-servant fails, since 'neither the immediacy and aestheticism of the master nor the asceticism of the slave is acceptable' and 'the point is to transcend the master/slave opposition', the dialectical process does not move backwards. The Phenomenology is constructed as a progression of self-consciousness towards newer and better understandings. By initially adopting one position, one comes to see its flaws and thereby discards it, while preserving any insights from it, in favour of a superior position, which will turn out to be flawed in turn, and so on. In the allegory of Hegel's that we have followed, there is nothing to suggest that, once the self-conceptions of the master and the servant have been transformed, they are at risk of collapsing back into their former delusions. What this means is that the identification with the product of his labour was a necessary step the servant had to take in order to achieve his freedom and self-sufficiency, and that this achievement cannot be taken away from him.

The transformations of self-conception involved in the master-servant allegory thus hold the promise of a kind of social reconciliation moving towards a less asymmetrical social order, one with newer, more accurate forms of recognition that tend towards equality and not domination.

\section{The contrast with Rancière}

For Rancière, as for Hegel, freedom and self-sufficiency do not arise out of improvements in material conditions, but out of transformations in self-conception. Freedom is first and foremost a changed relationship to what is given in sense. He makes this point through the story of a floor-layer who deliberately takes on a more precarious working arrangement as a 'jobber' because he enjoys the experience of freedom that it brings: 
The jobber frees himself by becoming less aware of exploitation and pushing aside, thereby, its sensory grip. He frees himself by nurturing a power of self-delusion. That power makes him work still more for the benefit of his enemy, against his own employment and the conservation of his health. But this counter effect, which results from his way of reframing the space and the time of exercise of his labor, is the source of a new pleasure, the pleasure of a new freedom. Such is the performance of equality that is meant by the word 'emancipation'. It is a subversion of a given distribution of the sensible.

- (Rancière, 2009: 277)

The point, as Deranty explains, is that 'people should always be assumed to be capable of thinking and acting [...] We should avoid descriptions [...] that lead to the conclusion that those suffering from [oppression] are fated to be crushed' (Deranty, 2010: 184). This lesson seems, on the face of it, to apply equally well to Hegel's master-servant dialectic. The servant is not crushed by his condition of servitude. Instead, he manages to realise a sense of his freedom and selfsufficiency within the limits of that servitude. In this general sense, Rancière's conception of freedom aligns quite closely with the experience of Hegel's servant.

One of Rancière's most important concepts is that of the distribution of the sensible, which he defines as a relation between 'being in a specific space and time, performing specific activities, and being endowed with capacities of seeing, saying, and doing that "fit" those activities' (Rancière, 2009: 275). In other words, a distribution of the sensible 'ties an occupation to a presupposition' (Rancière, 2009: 275). It is what holds in place the relations between social positions and social functions. It is what maintains the social order. In the Hegelian context, the distribution of the sensible is what holds the master and the servant in their hierarchical relationship.

The distribution of the sensible, crucially, has to do with self-conceptions and with conceptions of others. The distribution of the sensible can be disrupted by individuals putting into practice different self-conceptions. Putting into practice different self-conceptions actually makes individuals different to what they are taken to be. In this respect, Rancière's account of individual subjectivity is similar to Hegel's under Brandom's interpretation. Brandom writes: 'Essentially selfconscious creatures accordingly enjoy the possibility of a distinctive kind of self-transformation: making themselves be different by taking themselves to be different' (Brandom, 2011:26). The floor-layer changes his self-conception via the 'power of self-delusion' and, for a moment, succeeds in changing who he is.

Politics, for Rancière, consists in this power of self-transformation, which is at the same time a power of equality. Equality he defines as 'a supposition to maintain in every circumstance' (Rancière, 1991: 138), or in other words, it must be taken as axiomatic. Equality refers to the capacity to overcome one's condition of oppression on one's own terms. Returning to our example of the jobber, we can see this self-transformation at work and its political significance. The jobber often finds himself distractedly gazing out of the window as if he owned the house in which he is laying the floor and the view it commands (Rancière, 2009: 279). The jobber, momentarily, takes himself to be the owner of the house by appropriating a particular kind of gaze. This taking himself to be different actually makes him different, because it reveals to him his fundamental equality to those he works for. This equality that is revealed to him has to do with the capacity for aesthetic appreciation. Rancière writes that 'the perspective gaze, that has long been associated with mastery and majesty, can be assumed and verified as a power of equality' (Rancière, 2009: 280).

That the jobber is able to enjoy the aesthetic pleasure of a picturesque scene is the work of equality being put into practice. He constructs a new sensible world - one in which he is the master of the house - and experiences the pleasures of that new distribution of the sensible accordingly. Rancière conceives of this as an experience of freedom that was achieved in a self-sufficient way. Without assistance, the jobber manages to overcome his condition of oppression, which is an achievement that consists in removing oppression's 'sensory grip'. However, the sensory world that he has constructed is unstable. It lasts only 'so long as he has not finished laying the floor' (Rancière, 2009: 279). Once his work comes to an end, the jobber is forced to confront once again the material concerns that dominate his life.

Herein arises a tension between Hegel and Rancière. The tension has to do with the role that labour plays in generating the sense of freedom and self-sufficiency. For Hegel, the servant's labour is essential to the servant's transformation of self-conception, because it is by labour that the servant produces an object he can identify with, and this identification is very important for the transformation. For Rancière, on the other hand, labour is essential, but only as the condition that is trying to be overcome. Freedom does not consist in identifying with the product of one's labour; it consists in being free of labour altogether. The characters that Rancière focuses on in one of his major archival works, Proletarian Nights, are all 
workers who want to resist 'the simple idea that the vocation of workers is to work' (Rancière, 2012: viii). Freedom, for these workers, means doing exactly what the master has the luxury to do, i.e. read literature, write poetry and discuss philosophy (Rancière, 2012: viii). In other words, freedom is crucially tied in with the verification of equality: those at the bottom of the social hierarchy (i.e. those who labour) demonstrating they are just as capable of aesthetic experiences as those at the top (i.e. those who need not labour).

Freedom and self-sufficiency are experienced in the political moment when the distribution of the sensible is disrupted, such as when the jobber adopts the gaze of the master while he is laying the floor. But the dominant distribution of the sensible, which Rancière calls the police, is always ready to re-impose order. That is why the jobber does not attain a permanent sense of his freedom and self-sufficiency, but rather must continually participate in 'a power of self-delusion' in order to have such experiences. The political moment is 'always on the shore of its own disappearance' (Rancière, 2010: 92). Freedom and self-sufficiency are processes that must continually be put into practice, unlike Hegel, for which they are permanent outcomes of the dialectical process.

The final point of comparison has to do with the constitution of the social order on the basis of asymmetrical recognition. In his book The Ignorant Schoolmaster Rancière tells the story of a nineteenth-century French pedagogue, Joseph Jacotot, who comes to a radical conclusion about 'explication' and the educational system. Jacotot's discovery is that:

Explication is not necessary to remedy an incapacity to understand. On the contrary, that very incapacity provides the structuring fiction of the explicative conception of the world. It is the explicator who needs the incapable and not the other way around; it is he who constitutes the incapable as such.

- (Rancière, 1991: 6)

To make Jacotot's claim explicit, what he is suggesting is that teachers derive their authority from their status as bearers of knowledge and might therefore have an incentive to protect that status by making others out to be incapable of acquiring knowledge without their assistance. The claim here is rather similar to the dialectical process by which the master comes to realise just how dependent he is on the servant in order to enjoy the freedom he takes himself to have. The difference is, however, that while the Hegelian master improves upon his self-conception by taking on board the insight of his dependency on the servant, the Rancièrean master only re-doubles his efforts to maintain control of the distribution of the sensible, and thus of the social order.

Hegel's master-servant dialectic seems to present an optimistic view about social relations. In Rancièrean terms, Hegel seems to imply that the distribution of the sensible almost inevitably resolves itself for the better in a process of social reconciliation that produces newer, more accurate forms of recognition of identity. By contrast to Hegel, Rancière is cynical about the distribution of the sensible and about any possibility for social reconciliation. It is for this reason that Deranty (2003: 144) calls Rancière a 'decidedly nondialectical' thinker. Rancière conceives of the 'master' and the 'servant' as locked in a perpetual struggle over the distribution of the sensible. When the servant upsets this distribution by putting into practice an alternative self-conception, the master quickly steps in to restore order. Although he does acknowledge that 'there is a worse and a better police' (Rancière, 1999: 31), Rancière gives us no guarantee of social progress, and this makes him useful for a project of politicisation, because he captures the intuition that politics never comes to an end there will always be domination and exploitation that must be resisted.

Rancière believes that the social order is inherently unjust because it is inherently hierarchical: there are always some who find themselves excluded from meaningful participation in it. True freedom, for him, 'cannot consist in any form of social bond whatsoever' (Rancière, 1999: 34). And yet, the inequality of the social order is ultimately grounded in unrecognised equality. Rancière writes:

There is order in society because some people command and others obey, but in order to obey an order at least two things are required: you must understand the order and you must understand that you must obey it. And to do that, you must already be the equal of the person who is ordering you. It is this equality that gnaws away at any natural order. - (Rancière, 1999: 16)

This latter formulation, 'it is this equality that gnaws away at any natural order', could suggest that the equality grounding the inequality of the social order works itself out through some dialectical process. But it would be a mistake to think the social order inevitably collapses upon itself. For Rancière, the only way for the social order to change is for the distribution 
of the sensible to be disrupted, and doing that requires political actors putting into practice alternate self-conceptions, ones which verify the power of equality and which force them to be recognised.

For Rancière, freedom and self-sufficiency are more like processes than permanent achievements. Constant political action is required in order to disrupt the distribution of the sensible and to manifest the truth of this freedom and selfsufficiency that is constantly being suppressed by the police. Crucially, freedom and self-sufficiency, for Rancière, have very little to do with identifying with the product of one's labour. The transformation of self-conception comes about due to the desire to appropriate a different kind of gaze, the gaze of the master, and to live a different kind of life, one free of labour altogether.

The crux of the difference between Hegel and Rancière is whether freedom and self-sufficiency are achievements that can be had within the limits of servitude, or whether they require an abolition of servitude altogether. Social justice, I think, requires a commitment to constant struggle. It is on this basis that Deranty has criticised Axel Honneth's (1996) Hegelianinspired ethics of recognition. Despite calling it the 'most robust model today for a renewed critical theory of society' (Deranty and Renault, 2007: 93), he argues that, in order to be truly effective in diagnosing social ills and facilitating political action, Honneth's ethics of recognition needs to be politicised, and he finds in Rancière important resources for this end:

The appeal of Rancière's political writings lies in the fact that it is a type of ethics of recognition, but one that also deals seriously with the phenomena of domination and exploitation, putting them at the conceptual heart of theory [...] [Rancière] puts alienation and scission at the heart of every (would-be) reconciled moment. It is a logic that truly gives the negative its full power.

- (Deranty, 2003: 150)

Critical theories, as a starting point, need to be cynical about the social order and about processes of recognition and reconciliation, in order to properly account for domination and exploitation and thus enable political action.

\section{Acknowledgements}

I would like to acknowledge the Larrakia people, upon whose land this article was written. Sovereignty was never ceded, nor a treaty ever signed. I would also like to thank Gene Flenady for helpful comments on an early draft of this article, and Naish Gawen for helpful comments on a much later draft. This one is for my mother, before whose tremendous capacity for love I find myself humbled every single day.

\section{References}

Berlin, I. (2002), 'Two Concepts of Liberty', in Hardy, H. (ed.), Liberty, Oxford: Oxford University Press, pp. 166-218

Brandom, R. B. (2011), 'The Structure Of Desire And Recognition: Self-Consciousness And Self-Constitution', in Laitinen, A. and H. Ikaheimo (eds), Recognition and Social Ontology, Leiden: Brill, pp. 23-52

Deranty, J.-P. (2003), 'Jacques Rancière's Contribution to the Ethics of Recognition', Political Theory, 31 (1), 136-56

Deranty, J.-P. (2010), 'Afterword', in Deranty, J.-P. (ed.), Jacques Rancière: Key Concepts, Durham: Acumen, pp. 183-88

Deranty, J.-P. and E. Renault (2007), 'Politicizing Honneth's Ethics of Recognition', Thesis Eleven, 88 (1), $92-111$

Hegel, G. W. F. (2018), The Phenomenology of Spirit, ed. and trans. T. Pinkard, Cambridge University Press (originally published as System der Wissenschaft. Erster Theil: Die Phänomenologie des Geistes by Goebhardt in 1807)

Honneth, A. (1996), The Struggle for Recognition: The Moral Grammar of Social Conflicts, trans. J. Anderson, Cambridge: MIT Press (originally published as Kampf um Anerkennung by Suhrkamp in 1992)

Houlgate, S. (2013), Hegel's Phenomenology of Spirit: A Reader's Guide, London: Bloomsbury

Hyppolite, J. (1974), Genesis and Structure of Hegel's Phenomenology of Spirit, trans. Cherniak, S. and J. Heckman, Evanston: Northwestern University Press (originally published as Genèse et structure de la Phénoménologie de l'esprit de Hegel by Aubier in 1946) 
Rancière, J. (1991), The Ignorant Schoolmaster: Five Lessons in Intellectual Emancipation, trans. K. Ross, Stanford: Stanford University Press (originally published as Le Maître ignorant: Cinq leçons sur l'émancipation intellectuelle by Fayard in 1987)

Rancière, J. (1999), Disagreement: Politics and Philosophy, trans. J. Rose, Minneapolis: University of Minnesota Press (originally published as La Mésentente: Politique et philosophie by Galilée in 1995)

Rancière, J. (2009), 'Afterword: The Method of Equality: An Answer to Some Questions', in Rockhill, G. and P. Watts (eds), Jacques Rancière: History, Politics, Aesthetics, Durham, NC: Duke University Press, pp. 273-88

Rancière, J. (2010), 'Ten Theses on Politics', in Corcoran, S. (ed. and trans.), Dissensus: On Politics and Aesthetics, London: Continuum, pp. 27-44

Rancière, J. (2012), Proletarian Nights: The Workers' Dream in Nineteenth-Century France, trans. J. Drury, London: Verso (originally published as La Nuit des prolétaires. Archives du rêve ouvrier by Fayard in 1981)

Williams, R. (1997), Hegel's Ethics of Recognition, Berkeley and London: University of California Press

To cite this paper please use the following details: Enciso, S.W. (2019), 'Hegel and Rancière on the Transformation of SelfConceptions and the Achievement of Freedom and Self-Sufficiency', Reinvention: an International Journal of Undergraduate Research, Volume 12, Issue 1, https://reinventionjournal.org/article/view/436. Date accessed [insert date]. If you cite this article or use it in any teaching or other related activities please let us know by e-mailing us at Reinventionjournal@warwick.ac.uk. 